\title{
Understanding the Multinational Game: Toward a Theory of Asymmetrical Federalism
}

Comparative Political Studies 44(5) 546-57I

(C) The Author(s) 201 I

Reprints and permission: http://www. sagepub.com/journalsPermissions.nav DOI: I0.1 I77/0010414010364350 http://cps.sagepub.com

\section{(SAGE}

\section{Christina Isabel Zuber ${ }^{\prime}$}

\begin{abstract}
This article presents a baseline theory of asymmetrical federalism in multinational states. Two arguments building on a game-theoretic foundation link central and regional elites' strategic choices to questions of federal stability. The first argument concerns the creation of asymmetrical institutions. In a confrontation game between the center and national minorities credibly threatening to exit the framework, the center's decision to grant asymmetrical autonomy ensures mutual cooperation. Yet by extending the level of autonomy for minority regions, federal asymmetry creates a third player, the nonadvantaged regions. Consequently, the second argument models asymmetrical federalism as a "nested game" where events in the ethnonational arena determine the payoffs in the federal arena. Asymmetrical federal rules turn out to be inherently unstable from a perspective that takes all actors in all arenas into account. A narrative of the development of Russian federalism exemplifies the theory.
\end{abstract}

\section{Keywords}

asymmetrical federalism, federal stability, secession, multinational states, Russian federalism, nested games

\footnotetext{
'University of Cologne, Germany

Corresponding Author:

Christina Isabel Zuber, University of Cologne, Seminar für Politische Wissenschaft, Gottfried-Keller-Strasse I, D-50 93I Cologne, Germany

Email:zuberc@uni-koeln.de
} 
Multinational states result from the incorporation of different nations with traditional homelands into a single state (Kymlicka, 1998, pp. 113-119). As a consequence, they are confronted with the challenge of having to accommodate national minorities, defined as cultural groups voicing claims to self-determination on a territorial basis (Keating, 2001, pp. 43, 61-62; Stepan, 2001, p. 327). ${ }^{1}$ Multinational federal systems address these claims through the institution of asymmetrical autonomy (Stepan, 2001, pp. 327-328). A national minority is given special (i.e., asymmetrical) autonomy to realize on a substate level what the dominant group enjoys on a state levelself-determination as a ruling majority (Kymlicka, 1998, p. 133).

Some degree of asymmetry is a feature of all, not just multinational federal, political systems (Watts, 1999c, p. 29). ${ }^{2}$ Substate units vary with regard to size, demographic strength, or climate conditions. These given geographic, cultural, social, and economic factors are commonly termed de facto or political asymmetries. They have to be differentiated from de jure or constitutional asymmetries where constitutional law treats constituent state units differently, granting some more self-governing powers than others (Burgess \& Gress, 1999, p. 53; Kymlicka, 1998, p. 130). This can be observed in full-fledged federations such as Canada, Belgium, Spain, India, and Russia but also in constitutionally decentralized unions such as South Africa and the United Kingdom (for a comprehensive overview of de jure asymmetrical autonomy arrangements, see McGarry, 2005, p. 304).

Although asymmetrical solutions are of high practical relevance because they try to answer to the specific challenges that arise from the nature of political cleavages in multinational settings threatened by secessionist conflict, academic understanding of the dynamics they introduce and the mechanisms through which they function is still wholly insufficient (Congleton, Kyriacou, \& Bacaria, 2003, p. 170; Keating, 1999, p. 86). Mostly on normative grounds, scholars dealing with multinational states agree on the need for establishing asymmetry to accommodate politically relevant claims to self-determination on a territorial basis (Agranoff, 1999b, p. 97; Burgess \& Gress, 1999, p. 53; Watts, 1999a, p. 134). The potential of asymmetrical systems to remain stable, however, is disputed, leaving open whether these solutions are desirable or detrimental (Watts, 1999c, p. 28). The original account of federal asymmetry provided by Tarlton (1965) was followed by a long period of scholarly silence. A seminal volume edited by Agranoff (1999a) rediscovered asymmetrical federalism in 1999. Since then, some scholars have contributed to the subject, however, mostly at the level of typology or with analyses of asymmetry in specific individual contexts (e.g., Burgess, 2008; Palermo, Hrbek, Zwilling, \& Alber, 2007; Rao \& Singh, 2004; Swenden, 2002; 
von Beyme, 2005). As a consequence, we still lack an analytical understanding of asymmetrical federalism that could yield an answer to the question, can federal asymmetry stabilize multinational states? ${ }^{3}$

Asymmetry can be defined as a feature of multinational federal systems through which nationality-based units (NBUs; home to national minorities) de jure enjoy more rights than regional-based units (RBUs; home to the national majority population) and maintain a differentiated relationship to the center (Kymlicka, 1998). This suggests that the stability of asymmetrical federal political systems depends on the interaction of a complex set of actors defined by both the majority-minority and the center-regional divide. This article accounts for these patterns of interaction and presents a baseline theory of asymmetrical federalism in multinational states that draws on a game theoretical foundation.

Section 1 presents the first argument, which concerns the creation of asymmetrical institutions. Given a situation where a national minority confronts the center and credibly threatens secession, the center's readiness to grant asymmetrical autonomy to the minority region solves the prisoner's dilemma and ensures mutual cooperation. Yet by extending the level of autonomy asymmetrically for minority regions (i.e., NBUs), federal asymmetry creates a third player, the nonadvantaged regions (i.e., the RBUs). Consequently, Section 2 models asymmetrical federalism as a "nested game" (Tsebelis, 1990) where events in the ethnonational arena (structured by the majority-minority divide) determine the payoffs in the federal arena (structured by the center-regional divide). Asymmetrical rules are shown to simultaneously facilitate outcomes aimed at abolishing and at maintaining the asymmetries and therefore turn out to be inherently unstable from a perspective that takes all actors in all arenas into account. Section 3 exemplifies theoretical insights through a narrative of Russian federal institution building in the 1990s, during the course of which the center and secessionist-minded regional minority elites negotiated what Watts (1999b) described as "the most complex current example of constitutional asymmetry" (p. 67). Section 4 concludes.

\section{Why Multinational States Follow Asymmetrical Rules}

Within game theoretic approaches, "a self-enforcing institution is one in which each player's behaviour is a best response" and "no one has an incentive to deviate from the behaviour associated with the institution" (Greif \& Laitin, 2004 , p. 633). Some of the more recent advances in federal theory have applied 
this concept of self-enforcing institutions to questions of federal stability, emphasizing that federal rules have to be self-enforcing for officials at all levels of government (De Figueiredo, McFaul, \& Weingast, 2007; De Figueiredo \& Weingast, 2005; Filippov, Ordeshook, \& Shvetsova, 2004). The theory of asymmetrical federalism presented here takes up these insights and links asymmetry and stability at the level of central and regional actors' choices to yield explicit arguments about whether asymmetrical arrangements restrain rule-deviant and motivate rule-abiding behavior or whether the opposite holds.

The most imminent threat to stability in any federal system is secession (Filippov et al., 2004, p. 13). A group of actors not only deviates from some but also aims at abandoning the whole given set of rules. In multinational states where national minorities aspire to self-determination, this problem is aggravated because the most obvious strategy to realize this goal is by creating another sovereign nation-state (Hechter, 2000, p. 116). The stability of multinational federal systems is therefore systematically challenged by their very nature as multination states where the center has to confront sovereignty claims of peripheral nations within the state's borders. The first argument about the origin of asymmetrical federalism departs from this point where a national minority challenges the existing multinational framework and aims at secession. At the same time, this starting condition determines the scope of the theory. It does not hold universally across multinational systems but depends on exogenous conditions that mobilize national minority secessionism. Possibly the most significant of such conditions would be a transition to democracy (Hechter, 2000, p. 93). But also established democracies such as Spain or Canada encounter secessionist challenges.

Young (1994) summarized the following particular characteristics of secession games as opposed to games describing the formation of polities:

In instances of potential secession, however, the starting point is the status quo. The definition of the community is contested. And rational individuals may be concerned more with their potential losses through secession than with their potential gains through the formation of new communities. Finally, real existing governments are prepared to deploy policies and power in order to influence those calculations of future costs, and to alter them in reality. (p. 222)

In line with these assumptions, consider the following scenario of a contested status quo in a multinational state: ${ }^{4}$ Territory $\mathrm{T}$ is the traditional homeland of a national minority. Both the national majority and the minority want to maximize power over $\mathrm{T}$ : the majority because it is part of the overall state 
territory in which it constitutes the majority (Chapman \& Roeder, 2007, p. 679), the minority because it believes to have "some prima facie historical claim" (Kymlicka, 1998, p. 140) over T. Both minority and majority are represented by their respective political elite, hereafter termed Mi and Ma. At the heart of T's significance lie natural resources, for example, an oil field. Revenue (R) from extracting the oil field constitutes the payoff to be gained from controlling $\mathrm{T} .^{5}$

Now consider the impact of institutions. In the most extreme case, a unitary framework without power-sharing institutions, Ma controls key state institutions and the state territory including $\mathrm{T}$ in virtue of demographic dominance. Mi is denied participation in decision making at the central level and special regional authority over T. Given oppression, any outcome is preferable to the present one for $\mathrm{Mi}$, hence no rational choice between strategies is available (Young, 1994, p. 228). In a federal power-sharing system, however, the situation is more complex. Ma still controls key state institutions in virtue of demographic dominance, yet the federal units enjoy a certain degree of subnational authority and keep some amount of the revenue from regional resources. The existing order thus allows $\mathrm{Mi}$ a rational choice over whether to stick to the rules associated with the status quo.

In a symmetrical federal system, $\mathrm{Mi}$ is likely to disagree with the institutional status quo because of a perceived inequality: Ma dominates not only central state institutions that receive the federal share of all regional revenue but also all RBUs keeping their respective share. Mi on the other hand controls only its NBU and keep only the regional share of R. Mi thus considers itself to be a relative loser within the symmetrical framework (McGarry, 2002, p. 434). Meanwhile, Mi could gain exclusive power over T through secession, shifting R fully to $\mathrm{Mi}$, a strong incentive to abandon the status quo. Conversely, incentives for Ma at both the regional and the central level of government to maintain the status quo are high.

At one point in time, Mi's discontent leads to credible threats to secession. Ma can insist on maintaining the contested status quo (defect) with the risk of having to fight a secessionist war in due time if Mi realizes its threat or agrees on a change of the status quo toward a new institutional framework that is more attractive for Mi (cooperate). Mi on the other hand has to choose whether to really push through with secession at any cost (defect) or agree to remain within the multinational state (cooperate), a choice that will depend on weighing the benefits of a new framework against the costs of secession, potentially involving a military confrontation with Ma.

In a conventional symmetrical military confrontation, the costs of conflict for the central state would be comparatively low, whereas the 
Table I. Confrontation Game

\begin{tabular}{lcc}
\hline Ma/Mi & Cooperates & Defects \\
\hline Cooperates & Institutional change $(\mathrm{IC})$ & Secession $(\mathrm{S})$ \\
& $3 / 3$ & $1 / 4$ \\
Defects & Status quo $(\mathrm{SQ})$ & Military confrontation $(\mathrm{MC})$ \\
& $4 / \mathrm{I}$ & $2 / 2$ \\
\hline
\end{tabular}

secessionist region would encounter higher costs because of the disparity of military capabilities. Nationalist conflict between peripheral minorities and states, however, is characterized by asymmetric warfare, which implies partisan and terrorist strategies of the prima facie weaker warring party, strategies that can level differences between even military superpowers and small armed groups (Münkler, 2003, p. 192). Therefore, both players have grounds to assume that they can succeed in reaching their most preferred outcome if they defect, even if the other player also chooses defection. If the payoff of the most preferred outcome also weighs out the potential cost of a confrontation for each of the two players individually, then their preferences regarding the outcomes depicted in Table 1 can be characterized with the following inequalities:

$$
\begin{aligned}
& \text { Ma: } \mathrm{SQ}>\mathrm{IC}>\mathrm{MC}>\mathrm{S} \\
& \text { Mi: } \mathrm{S}>\mathrm{IC}>\mathrm{MC}>\mathrm{SQ}
\end{aligned}
$$

Under the assumption of these simple ordinal preference rankings, the game between a national majority and one or several national minorities takes the form of a prisoner's dilemma. Both actors have a most preferred outcome (secession for Mi and maintenance of the status quo for Ma) they can gain if they defect unilaterally while the other player cooperates. Although mutual cooperation could yield a Pareto superior outcome, mutual defection (i.e., military confrontation) is the equilibrium solution of the game.

This is where asymmetrical autonomy enters the equation. Remember that the relationship between the players is hierarchical and that Ma has the possibility to "deploy policies and power in order to influence those calculations of future costs, and to alter them in reality" (Young, 1994, p. 222; see above). If we move away from purely ordinal preferences and allow variable payoffs, an offer of asymmetrical autonomy by Ma can fill the outcome of institutional change departing from the status quo with substance and change the 
payoff matrix in favor of cooperation for $\mathrm{Mi}^{6}{ }^{6}$ The simplification of revenue $\mathrm{R}$ as the payoff gained from controlling $\mathrm{T}$ can clarify this role of asymmetry: The status quo payoff for $\mathrm{Mi}$ in a symmetrical federation equals $\mathrm{R}-\mathrm{F}$, with $\mathrm{F}$ being the federal share. Successful secession leads to full R. At the same time, however, secession implies an exit cost, C. So the benefit of secession is $\mathrm{R}-\mathrm{C}$, whereas the benefit of cooperating within the federation is $\mathrm{R}-\mathrm{F}$. Cooperation is the superior strategy if $\mathrm{R}-\mathrm{F}>\mathrm{R}-\mathrm{C}$. The role of asymmetry is to lower the value of $\mathrm{F}$ so that this inequality holds by allowing Mi to keep a larger share of $\mathrm{R}$ than regions on average are allowed to keep. The cooperative solution that meets the challenge of secession without resorting to violence is an asymmetrical deal granting special conditions to Mi.

But not only does asymmetry change the payoff matrix that makes cooperation more likely, it can actually solve the prisoner's dilemma by providing for a contract in the form of a de jure guarantee of special autonomy. A binding contract between players in a prisoner's dilemma ensures mutual cooperation because it enables the players to correlate their strategies and achieve the Pareto optimal outcome (Tsebelis, 1990, p. 108). In the case of de jure asymmetry, Ma's readiness to cooperate, that is, accept that the status quo moves from symmetrical to asymmetrical federalism, is written down in the constitution or a document with the status of constitutional law. As this document is mutually agreed on by both sides, this comes down to players stating, "I cooperate because my opponent cooperates," hence the Pareto optimal outcome can be achieved.

In short, a minority's readiness for secession encountered by the center with an offer of asymmetrical autonomy explains the shift from an institutional equilibrium of symmetrical to asymmetrical federalism. This is the game theoretical explanation for why de jure asymmetries are vital in multinational states, an opinion so far defended on normative grounds in the literature (Requejo, 2001, p. 45).

\section{How Asymmetrical Rules Challenge Federal Stability}

But the question of institutional stability in multinational states is not settled with a successful asymmetrical deal struck between national majority and minority political elites. The confrontation game does not take place in a "vacuum"-it is embedded in the "higher order network" (Tsebelis, 1990, p. 245) of the federal game. The success of stabilizing relations between the majority and secessionists has to be put in perspective with the overall functioning balance of federal systems where - in the absence of third party 
enforcement - outcomes of any bargain have to be self-enforcing and where central negotiations with officials of one subnational unit do not stand in isolation but affect the bargaining strategies chosen by others (Solnick, 1998, p. 59). Asymmetry establishes a problematic link between these two aspects: Because negotiation between the center and the nationality-based regions does not stand in isolation, the asymmetrical federal institutions turn out to be not self-enforcing.

Already back in his early account of federal asymmetry, Tarlton (1965) had anticipated the challenges asymmetry poses for the stability of federal systems:

It should be stressed at this point that where state-federal conflict occurs it is most likely to stem from complaints limited to one or just a few of the member states. It is rare for conflict to occur between the central government and all [italics original] the states simultaneously. Therefore federal state conflict is a likelihood where the relationship between local and central authorities corresponds to the image of the asymmetrical situation, and where that asymmetry is characteristic of only a few of the states in their relation to the whole. To a real extent, then, the degree of harmony or conflict within a federal system can be thought of as a function of the symmetrical or asymmetrical pattern prevailing within the system. (p. 871)

Game theory can specify Tarlton's original "theoretical speculation., "Federalism is usually modeled as an $\mathrm{N}+1$ game taking place between $\mathrm{N}$ federal units and the center (e.g., Bednar, 2009, p. 14; De Figueiredo \& Weingast, 2005, p. 110). In the case of multinational asymmetrical federalism, however, the federal game extends to three types of players: executive officials of units with special status, executive officials of units with average status, and officials at the level of the federal government $\left(\mathrm{N}_{\text {special }}+\mathrm{N}_{\text {average }}+1\right)$. The types of players can be differentiated by their goals regarding the overall nature of the system: Officials of units with special status demand that an asymmetrical deal be maintained, as only asymmetry can make the national minority population they represent equal in terms of national selfdetermination (McGarry, 2002, p. 434). Catalan leaders, for example, refuse to accept that Catalonia is treated like the other nonoriginal autonomies in Spain (Stepan, 2000, p. 146). Likewise, Quebec leaders in Canada strongly oppose the idea that Quebec could be classified as an ordinary province on par with the nine English-speaking ones (McGarry, 2005, p. 308). 
Officials in average units at their turn aspire after an upgrade to the stronger powers of the special units emphasizing the "principle of equality of units" (McGarry, 2002, p. 434). They demand café para todos (coffee for everybody), an expression commonly used in the Spanish case to describe the process whereby the asymmetrical powers originally devolved to the historic regions are being extended to other regions as well (Agranoff, 1999b, p. 108). ${ }^{8}$ Although the center could be confronted with different types of units also in de jure symmetrical federal systems (e.g., economically stronger vs. weaker regions, as analyzed by Hug, 2005), de jure asymmetry institutionalizes differences between players at the level of the rules of the federal game. As a consequence, the center is confronted with bargaining coalitions characterized by institutional interests that are more stable than the issuebased ad hoc coalitions between equal units in a more symmetrical system. This could be a reason why in the Spanish case the central government aims at a symmetrical solution in the long run (Agranoff, 1999b, p. 107).

As a consequence of previous interaction between national minority and national majority elite, the overall federal game now involves three instead of two types of players. From this perspective, it is not enough for asymmetrical rules to be a self-enforcing solution to the confrontation game. The new institutional rules have to prove stable in the federal arena as well, where a third party or an additional set of players has to be taken into account: officials at the level of the RBUs. Asymmetrical federalism therefore constitutes a prime case for an application of Tsebelis's (1990) theory of "nested games" with its focus on the impact of reactions of third parties to the interaction of the main players (Tsebelis, 1990, pp. 59-60). RBUs' choices of strategy in the federal arena (structured by the center-regional divide) are affected by the asymmetrical powers granted to one or several NBUs in the ethnonational arena (structured by the majority-minority divide). Officials of RBUs turn out to be relative losers in an asymmetrical framework, whereas they used to be relative winners under symmetrical federal institutions. Relative payoffs are thus crucial not only for national minority officials in the NBUs but also for officials of RBUs observing the relatively stronger position of the NBUs. Officials at the level of RBUs face strong incentives to challenge the asymmetrical institutions that imply a shift to a relative disadvantage for them. This provides grounds for the RBU to initiate an upgrade game with the central player and demand an increase in regional autonomy.

Table 2 illustrates the upgrade game that is initiated by the RBU in reaction to events in the ethnonational arena. Central officials can again insist on defending the institutional status quo (defect) - which is asymmetrical as a 
Table 2. Upgrade Game

\begin{tabular}{lcc}
\hline Center/Regional-based unit & Cooperates & Defects \\
\hline Cooperates & Upgrade deal (UD) & Peripheralization (P) \\
& $3 / 3(4 / 4)$ & $2 / 4(2 / 3)$ \\
Defects & Status quo (SQ) & Failed federation (FF) \\
& $4 / 2(3 / 2)$ & $\mathrm{I} / \mathrm{I}(\mathrm{I} / \mathrm{I})$ \\
\hline
\end{tabular}

consequence of the game in the ethnonational arena-or agree to reform (cooperate), whereby reform implies raising the level of autonomy for the RBU. The RBU can choose to cooperate, which implies potential acceptance of an unchanged asymmetrical status quo, or defect, that is, extend regional competencies unilaterally without consent of the federal center.

Although it is plausible to assume that both players as members of the national majority would above all seek to avoid a failure of the federation, the following variations of preference orderings are possible: If the center values the asymmetrical contract constituting the status quo higher than the outcome of mutual cooperation, the game is likely to resemble a game of chicken with the following preference orderings:

$$
\begin{gathered}
\text { CENTER: } \mathrm{SQ}>\mathrm{UD}>\mathrm{P}>\mathrm{FF} \\
\text { RBU: } \mathrm{P}>\mathrm{UD}>\mathrm{SQ}>\mathrm{FF}
\end{gathered}
$$

No obvious choice between the two equilibria of maintaining the asymmetrical status quo or regions' unilateral extension of authority exists (see payoff combinations without parentheses in Table 2) and the player that makes the first move can force his or her most preferred outcome on the other. Given that the threat of regional noncompliance with the federal rules is credible (i.e., voiced by one of the stronger regions) and the outcome of a peripheralized federation is likely, ${ }^{9}$ anticipating officials at the central level can therefore be tempted to strike a cooperative upgrade deal with the RBU even though this undermines the asymmetrical contract binding them in the ethnonational arena because it constitutes a way to ensure their interests. Correspondingly, Solnick (1998, p. 62) describes a central strategy of "divide and rule" where the center engages in special ad hoc deals with some of the stronger average regions as a characteristic feature of asymmetrical federalism. In this case, officials at the central level of government value the outcome of mutual cooperation higher than maintaining the status quo and might be 


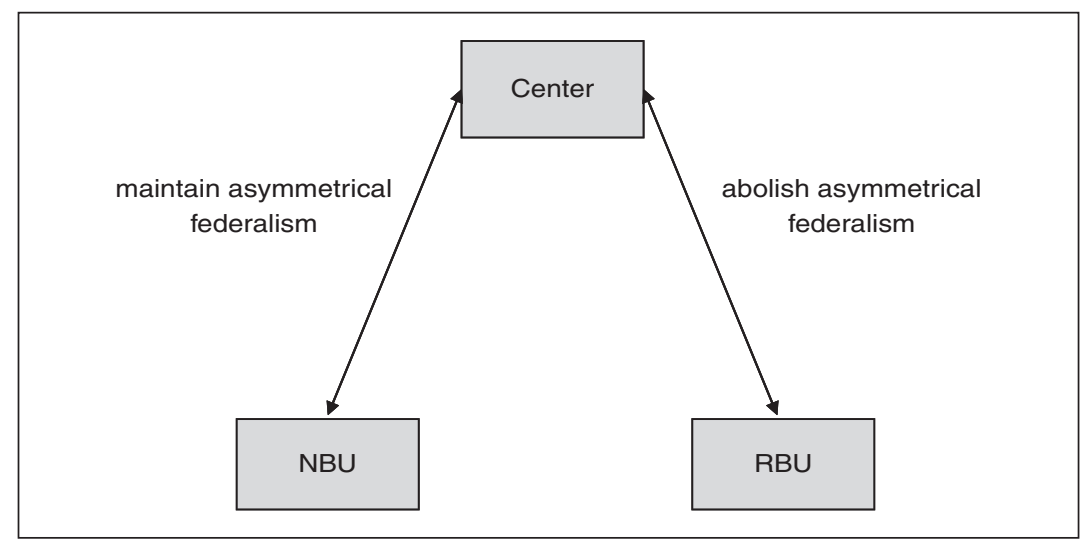

Figure I. The nested game of multinational federalism

interested to use their institutionally dominant position to make a substantial autonomy offer that turns cooperation into the most preferred outcome also for the RBU:

$$
\begin{gathered}
\text { CENTER: UD > SQ > P > FF } \\
\text { RBU: } \mathrm{UD}>\mathrm{P}>\mathrm{SQ}>\mathrm{FF}
\end{gathered}
$$

Given these new preference orderings, three equilibria exist (see Table 2, payoff combinations in parentheses), and both players can anticipate that the other side will cooperate as mutual cooperation provides the highest payoff and is thus the Pareto optimal solution (Tsebelis, 1990, p. 64).

What does all this tell us about the stability of asymmetrical federalism? Figure 1 displays the multinational game as a network of games in the ethnonational and the federal arenas. The central player is involved in two bilateral games, the confrontation game with the NBUs and the upgrade game with the RBUs. The two games provide diverging incentives for central choice of strategy.

Although the cooperative solution that avoids military confrontation with the NBUs demands asymmetrical federalism, striking a deal with the RBUs can imply upgrading average units and thus in the last instance symmetrical federal rules. ${ }^{10}$ Reaching a cooperative solution with one type of regional officials thereby involves undermining the prospects for cooperation with the other. This reverses but remains in line with the logic of the games presented in Tsebelis's original account of nested games where prima facie suboptimal strategies turn out to be optimal from a perspective that takes the whole network 
of games into account (Tsebelis, 1990, p. 7). In the case of multinational asymmetrical federalism, optimal strategies exist in both games central officials are involved in, but these are mutually exclusive at the level of the nested multinational game. By creating three types of players, asymmetry thus institutionally facilitates center-regional cooperation aimed at maintaining the asymmetrical solution (special regions and center) and at abolishing it (average regions and center) at the same time.

Adding an additional threat to stability, central officials are more likely to undermine federalism in asymmetrical systems because the institutionalized differences make it harder for the units to coordinate on punishment strategies against central attempts to overawe them, a crucial condition for self-enforcing federalism in De Figueiredo and Weingast's (2005, p. 127) model. Rather than having the regions coordinate against it, the center can choose between coalition partners and maximize its own power.

To summarize, although Section 1 has shown that asymmetry lowers minority actors' incentives to deviate from the existing framework and establishes a cooperative equilibrium governing the conflictive relations between a national minority and the national majority, the nested games argument holds that asymmetrical institutions are not self-enforcing when taking the motivations of actors in both the ethnonational and the federal arenas into account. The original sequence of the two games is thereby theoretically meaningful: Without a prior compromise on asymmetrical distribution of power, there are only two types of players and average equilibrium models of federalism apply. The logic of the multinational game on the other hand applies whenever a mobilized national minority challenges the central state (i.e., opens up the ethnonational arena) in an already federal system or when the settlement of an ethnic conflict leads to an asymmetrical federal arrangement in a formerly unitary state (i.e., adds the federal arena to the already existing ethnonational one). Challenges to institutional stability should therefore constitute a systematic feature of multinational federal systems.

\section{Asymmetry in the Russian Federation}

The following section exemplifies theoretical insights gained so far through a narrative of Russian federalization. A Russian plausibility probe of the theory has the advantage of illustrating multiple implications of the theory within a single case (George \& Bennett, 2005) given that political authority was divided and redivided several times involving highly asymmetrical assignments of regional autonomy during the 1990s. Although the literature has described this as an idiosyncratic process driven by Russian 
particularities (Kahn, 2002; Umnova, 1996), the baseline theory of asymmetrical federalism offers a systematic explanation that draws on the logic of the games presented above. ${ }^{11}$ The narrative is divided into three phases. The first phase starts with the separatist challenges arising in the ethnonational arena during the dissolution of the Soviet Union and ends with the asymmetrical solution stipulated by the provisions of the Federal Treaty of 1992 (FT). The second phase analyzes the three players' negotiation behavior during the nested game of constitutional bargaining in the summer of 1993. The third phase focuses on the series of asymmetrical bilateral treaties signed by the center and individual units between 1994 and 1998 that were driven by the sequencing of confrontation and upgrade games. ${ }^{12}$

\section{I. Post-Soviet Separatism and the Asymmetrical Federation Treaty of 1992}

Within the overall upheaval of nationalism and restructuring of state borders that was taking place during and in the aftermath of the dissolution of the Soviet Union, a window of opportunity opened for national minority elites to challenge former state boundaries as new frameworks were yet to take shape. According to data collected by Treisman (1997, pp. 226-228), political leaders in 25 NBUs, both autonomous Soviet socialist republics (hereafter ASSRs) and autonomous areas, declared sovereignty in 1990 and 1991. This initiated the confrontation game in the ethnonational arena. Out of these sovereignty declarations, the ones of the republics of Tatarstan and Checheno-Ingushetiya were the most far-reaching. Whereas the other regions defined their sovereignty within Russia, both of these ASSRs defined their sovereignty as independent states (Heinemann-Grüder, 2000, p. 131). The Checheno-Ingush document declared the republic a "sovereign state constituted as a result of the self-determination of the Chechen and Ingush people" (as cited in Tishkov, 1997, p. 56). The Tatar declaration was more inclusive with regard to other nationalities but equally ambitious, declaring state sovereignty with reference to neither Russia nor the Soviet Union but as the "realization of the inalienable right of the Tatar nation, of all people of the republic to self-determination" (as cited in Tishkov, 1997, p. 56).

This established elites in Tatarstan and Chechnya as the players who would pose the most serious challenges to the territorial integrity of the new Russian Federation, having openly stated that their preferred outcome of the confrontation game would be a sovereign state. The other sovereignty declarations were less radical and in case of the former ASSRs primarily aimed at maintaining the status of a republic with state character and at being 
recognized as voluntary and equal signatories to the Federation Treaty under preparation (Heinemann-Grüder, 2000, p. 131). Nevertheless, they were declarations of sovereignty, that is, acts of defiance, issued by territories sometimes much larger than former Soviet Union republics that were in fact becoming sovereign independent states, and they came at a time when ethnopolitical mobilization was at its height all across Eastern Europe (Gorenburg, 2003, p. 126). ${ }^{13}$

Achieving an accepted framework of rules was vital to counterbalance the centrifugal dynamics arising from sovereignty claims and nationalist mobilization. Under these conditions, actors opted for an asymmetrical legal base in form of the FT of March 31, 1992, that was attached as an annex to the Russian Constitution of 1978 (Umnova, 1998, p. 53). The FT distributed powers unevenly across three categories of units:

1. natsional'no-gosudarstvennye respubliki (nation-state republics)

2. natsional'no-territorial'nye obrasovaniya (national-territorial entities)

3. administrativno-territorial'nye obrasovaniya (administrativeterritorial entities)

Each of these groups signed a separate subtreaty with the center; all three texts together constituted the FT (Federativnii Dogovor, 1992). The existence of three different treaties deepened asymmetrical differences between the categories of federal units (Medvedev, 2003, p. 23). The Russian Federation thus started off as an asymmetrical political system with 21 republics, 11 autonomous areas, and 57 Russian units - not only preserving but further extending the Soviet ethnoterritorial principle of federalism that had traditionally divided the state into NBUs and RBUs.

The substantial de jure asymmetries the center conceded to the NBUs (i.e., Categories 1 and 2) to make the common framework more attractive were considerable: In their part of the treaty, republics were acknowledged as gosudarstva (states) (Federativnii Dogovor, Subtreaty With Republics, 1992, art. III.1) and vested with powers to decide about the nature of their regional political order (Federativnii Dogovor, Subtreaty With Republics, 1992, art. III.1). The treaty further stipulated the land and all natural resources as the property of the peoples inhabiting the republican territory (Federativnii Dogovor, Subtreaty With Republics, 1992, art. III.3). The treaty with national-territorial units (i.e., the autonomous areas) contained a clause that allowed the units to take measures for the protection and advancement of the 
traditional way of life of inhabitants (Federativnii Dogovor, Subtreaty With National-Territorial Units, art. III.3).

The asymmetrical rules satisfied the aspirations of most of the regions that had declared their sovereignty (Heinemann-Grüder, 2000, p. 153). Mutually signed by the center and the regions in consensus, the treaty established the first set of asymmetrical rules for the new Russian state. These proved acceptable for most of the separatist-minded NBUs that had aspired to independence in the aftermath of the dissolution of the USSR. Republics that had openly declared their sovereignty in 1991 were now willing to sign what was not an international treaty between independent states but an agreement between federal units and the federal center.

Yet the cooperative asymmetrical solution of the confrontation game was incomplete: The two republics that had most strongly expressed a desire for independence, Tatarstan and Chechnya, remained unconvinced of the framework set out in the FT and continued to defect, defining themselves as independent states (Heinemann-Grüder, 2000, p. 145). The clearest sign of this was that both republics refused to sign the FT in 1992. The process of accommodating national sovereignty demands raised during the transition period remained unfinished as the relations of two regions to the overall system still lacked a legal basis. The asymmetries of the FT did not prove significant enough to make cooperation and rule acceptance a real alternative to defection for regional elites in Chechnya and Tatarstan.

\subsection{The Russian Constitutional Bargain of 1993}

The drafting and the adoption of the constitution of 1993 constituted the next step in the establishment of modern Russian federalism. The asymmetrical differences between NBUs and RBUs institutionalized in the FT as a result of the confrontation game in the ethnonational arena conditioned the types of players for the negotiations in a constitutional assembly convened by Yeltsin in July 1993. Representatives from the republics expressed fears of being dominated by the Russian majority and aspired toward a confederation of "free nations." Among them, the Tatar delegates were to present the toughest position, as Chechnya had refused to participate (Hughes, 2002, p. 48). The RBUs should not even be part of the constitutional negotiations that were to take place only between sovereign nations. Furthermore, Tatar sovereignty would allow only a parallel, not a superior, sovereignty of the Russian Federation (Heinemann-Grüder, 2000, pp. 166-167). Only highly asymmetrical constitutional rules would be acceptable for the representatives of the NBUs. 
Representatives of the Russian RBUs opposed this approach. They feared the marginalization of the Russian majority in a scenario that left unclear how the Russian demos could be sufficiently represented in a confederation composed of nations. The major conflict line in the assembly thus ran between republics and Russian RBUs who had opposing ideas about the structural nature of the emerging federal system. Whereas the group of republics pushed for the equality of sovereign nations, the Russian regions made equality of units their condition for approval to the draft constitution (Heinemann-Grüder, 2000, p. 167). This corresponds to the assumptions about the diverging goals of NBUs and RBUs in multinational states outlined above.

The center was playing in both arenas, as illustrated in Figure 1 (see above), and took advantage of the situation. In the privileged position of being a potential coalition partner for both sides in a divided constitutional assembly, Yeltsin managed to strengthen the institution of presidential office considerably. The draft constitution granted the president the right to take measures defending the sovereignty of the Russian Federation, to nominate judges for the constitutional court, to call referenda, to declare regional legislation contradicting the constitution invalid, to call a state of emergency, to rule by decree, and to veto legislation that could then be adopted only with a two thirds majority in both chambers (Heinemann-Grüder, 2000, p. 168).

In the end, the difficulty of striking a constitutional bargain that set the rules for the multinational game given the diverging goals of asymmetrically institutionalized players became obvious when the constitutional assembly failed to reach consensus. Any outcome that would emerge from bargaining between the center and RBUs proved unacceptable for the NBUs and vice versa. The Tatar delegation walked out of negotiations, and Yeltsin dissolved parliament and imposed a plebiscite on his preferred version of the new constitution by decree (Hughes, 1996).

The president's version of the constitution stipulated the equality of federal units (Konstitutsiya, art. 5, par. 1) as demanded by the RBUs. This had been one of the most heatedly disputed formulations in the assembly. Consequently, the constitution was not supported by the larger part of the population in the nationality-based republics. ${ }^{14}$ Not satisfying the republics more generally, the constitution was, as one might by now expect, most significantly opposed by Tatarstan and Chechnya, where regional leaders successfully called for boycott of the constitutional plebiscite. Yet the same article that stipulates equality of units in the first paragraph maintains asymmetrical status for republics in the second. Republics are entitled to their own constitution whereas other units merely have charters (Konstitutsiya, art. 5, par. 2). This attributes a clear characteristic of statehood to the republics only. 
Despite discontent by the republics, the Russian Constitution thus provided a de jure asymmetrical framework maintaining the division of units into three categories stipulated by the FT (Obydenkova, 2005, p. 266).

\subsection{The Bilateral Treaty Process, 1994-1998}

The basic constitutional asymmetries were substantively aggravated and complicated from 1994 onward, when the center entered a process of negotiating and signing bilateral treaties with some regions individually to specify-and asymmetrically modify - the delimitation of jurisdiction laid out in the constitution of 1993. In some of the treaties, areas of jurisdiction were asymmetrically shifted between levels of power, for example, from the level of joint to the level of regional competencies. Bilateral treaty provisions thus increased the areas of jurisdiction for some regions - one of the procedures for establishing asymmetrical federalism (Watts, 1999c, p. 37). Although the first set of treaties was concluded with NBUs, later bilateral upgrade deals with some of the RBUs broke the systematic link between the nationality-based character of units and special asymmetrical status established in the FT and confirmed in the constitution. Between the first treaty with the republic of Tatarstan in February 1994 and the last with the federal city of Moscow in June 1998, 46 bilateral treaties were negotiated between regional and central organs of state power. 15

The first wave of treaties (1994-1995) included only NBUs and more specifically only republics. Yeltsin had recommended a strategy of asymmetrical accommodation already in April 1992, shortly after the FT was signed-respectively not signed by Tatarstan and Chechnya. He suggested that extended asymmetrical terms should be offered to these two republics as an incentive to remain within the Russian Federation (Heinemann-Grüder, 2000, p. 153). This corresponds to the logic of the confrontation game. In light of secessionist threats, the center can choose to offer special conditions to minority elites, and this was the official position of the Yeltsin government (Obydenkova, 2005, p. 263). The first and most powerful bilateral treaty in terms of asymmetrical autonomy granted was consequently signed with Tatarstan on February 15, 1994. This time, the autonomy offers were substantial enough for regional elites in Tatarstan to choose cooperation. In return for Tatarstan's readiness to remain an integral part of the Russian Federation, the center accepted what has been described as "a co-sovereignty arrangement" (Hughes, 2002, p. 51) with the republic. The treaty's preamble recognizes the republic of Tatarstan as a gosudarstvo (state) that is ob'edinena (united) with the Russian Federation (Dogovor Rossiiskoi Federatsii i Respubliki Tatarstan, 1994, Preamble); none of the other treaties were to make such far-reaching references to sovereignty. 
Unlike in the case of Tatarstan, the center never offered negotiations over an asymmetrical deal to Chechnya, like it had originally envisaged. As no increased payoffs within the federation were in sight, regional secessionist forces under the leadership under Dudaev increasingly gained support (Alexseev, 1999, p. 255). Without an asymmetrical deal, the equilibrium outcome of the prisoner's dilemma was military confrontation. The center thereby gave a powerful signal to regional elites that it would rather seek confrontation than accept their formal independence (Alexseev, 1999, p. 264).

The first treaty with Tatarstan was soon followed by treaties with the republics of Kabardino-Balkaria (July 1, 1994) and Bashkortostan (August 3, 1994). These were all NBUs that had been playing the separatist card at the beginning of the 1990s. Bashkortostan had a vivid national revival movement, and nationalist protests, though not as intense as those in Tatarstan, were frequent in the republic (Gorenburg, 2003, p. 126). Kabardino-Balkaria is one of Russia's northern Caucasus republics (like Chechnya, North Osetiya, Dagestan, Ingushetiya, and KarachaevoCherkessiya), a region on the whole characterized by high levels of ethnic conflict (Stepanov, 2000, pp. 308-315).

The treaties substantially raised the benefit of cooperation for the nationality-based republics. To give some examples, Tatarstan and Bashkortstan were granted the use of land and natural resources and even the right to establish a national bank, originally an exclusive federal competence. Regional budgets varied accordingly: Of all taxes raised regionally in 1996, Tatarstan kept a share of $84.7 \%$ and Bashkortostan one of $71.2 \%$, compared to the $56.8 \%$ kept by regions on average (figures taken from Heinemann-Grüder, 2000 , p. 383). The first wave of treaties was thus characterized by the logic of the confrontation game, enhancing asymmetries for minority regions individually, whereas failure to opt for asymmetry to make an institutional solution more attractive led to mutual defection in the military confrontation with Chechnya. ${ }^{16}$

Again, the outcome of interaction between the center and the NBUs had an impact on the relations between the center and RBUs. The first treaty with a Russian region was signed with Sverdlovsk on January 12, 1996. In terms of central interests, ensuring the compliance of separatist regions was now replaced by the aim of securing Yeltsin's reelection in the presidential elections of July 3, 1996, as the center shifted attention from the ethnonational to the federal arena. Like in the case of constitutional bargaining, the outcome of asymmetrical federal rules in the ethnonational arena not only offered incentives for officials in RBUs to challenge the asymmetrical framework and move it in the direction of symmetry but also motivated central officials to use the upgrade game with the RBUs for their own purposes of extending power and securing office. 
Sverdlovsk under the powerful leadership of governor Eduard Rossel was a key advocate of the extension of asymmetrical autonomy to RBUs. The rich region claimed the status of a republic and even declared itself a state in 1993 (Hughes, 1996). Rossel's argument for the founding of a "Ural's republic" was again the equality of units. In an interview in July 1993, he emphasized "the necessity of economic equal rights of regions" and stated that "tax assessment of the territories should be equal. Nothing else is worth the idea of the Urals Republic" (as cited in Herrera, 2005, p. 203). Rossel thereby gave several signals that he was ready to make the first move in the upgrade game played as a game of chicken. To prevent the outcome of peripheralization, the center granted Sverdlovsk special powers in a bilateral treaty in 1996. RBUs that were left out complained that the process was destroying the federal system, but once having complained loud enough, they were soon pacified with their own bilateral treaty (Filippov et al., 2004, p. 135).

The treaties from summer 1997 onward can be attributed to a formal effort by the center to roll back regions' asymmetrical power. The importance of earlier treaties was to be diminished as standardized ones were offered to most regions. The intention was to equalize regions and make the system as a whole less asymmetrical (Filippov et al., 2004, p. 136). Of course such an attempt was exactly what some of the republics had feared and strongly opposed because it constituted a loss in relative power for them. Already in 1995, Tatarstan, Bashkortostan, and Sakha had issued a joint declaration demanding that any negotiation over new treaties should have to take into account the substantial differences between the three types of federal units, that is, republics, autonomous areas, and RBUs (Hughes, 1996). The practice of bilateral treaties had so far secured and manifested the special status of the NBUs. It was now beginning to be directed at undermining it.

\section{Conclusion}

The narrative shows how a game theoretical approach can explain the prima facie incoherent federalization process in the Russian Federation. Although separatism could be mitigated through asymmetrical deals, the system has been caught up in continuous bargaining over its concrete design with strong incentives for RBUs to enter an upgrade game with the center in the federal arena. Their demand for equality of units clashed with the asymmetries that emerged as cooperative solutions in the ethnonational arena. "Disagreement over the 'soul of a working federalism,"” for Kahn (2002) the "fundamental problem facing the Russian Federation" (p. 81), is in light of the perspective of the nested multinational game a feature all asymmetrical federal systems should have to cope with. ${ }^{17}$ 
Beyond explaining Russian federalization, the analytical perspective suggested here has both important theoretical and practical implications. With regard to theoretical controversy about federal stability in asymmetrical systems mentioned in the introduction, it now appears crucial to separate the function asymmetry performs as a binding contract that solves the confrontation game (stability enhancing) from the function asymmetry performs as a structural principle of the overall federal system (not self-enforcing and therefore stability challenging). From this perspective, stability arguments in favor and against asymmetrical federalism are not mutually exclusive but can be true at the same time.

On the practical side, and counterintuitive to the high visibility of secessionist conflict and national minority actors driving it, the survival of multinational federal systems hinges not only on their readiness to accept the rules of the game and refrain from separatist acts of defiance but also on the willingness of the RBUs to let de jure asymmetrical rules that resulted from a deal struck in the ethnonational arena structure the game in the principal federal arena of which they constitute a legitimate part. They face high incentives to deviate from asymmetrical federalism that defines them as the relative losers of the federal institutions. It is therefore likely that they will challenge the institutional equilibrium installed to prevent secession. In the Russian case this happened both throughout constitutional bargaining and during the bilateral treaty process.

So far, debate about the benefits and risks of federalism in multinational contexts has turned a blind eye to officials at the level of RBUs and has predominantly focused on the effects of a federal power-sharing arrangement on minority separatism (for a summary, see Treisman, 2007, pp. 236-246). Federal theory on the other hand has applied game theory to model strategic interaction between the center and all federal units in symmetrical federations (De Figueiredo \& Weingast, 2005) yet has not been paying special attention to the challenge of multinational heterogeneity. The analysis presented here shows that a comprehensive theory of asymmetrical federalism has to connect these two strands of literature as the multinational federal game cannot be understood unless the coexistence of the ethnonational and the federal arenas is taken into account. But just like the state of the art in theories of symmetrical federalism suggests, ultimately a theory of asymmetrical federalism also has to move beyond equilibrium analysis to account for the adaptability of federal systems (Bednar, 2009, chap. 7) and explain why multinational federations survive over time, given the destabilizing incentives of asymmetry. Although such a comprehensive theory of asymmetrical federalism is yet to be completed, the baseline presented here shows that asymmetry can no 
longer be treated as a coincidental abnormality within a universe of purely symmetrical federal systems. As a systematic (albeit problematic) feature of multinational federal states, it deserves theoretical interest beyond the occasional typological remark.

\section{Acknowledgments}

I thank all members of the chair in comparative politics at the University of Cologne for their constructive comments on an earlier version of this article. Particular thanks go to Annika Hennl, André Kaiser, and Jan Sauermann for inspiring the game theoretical approach to asymmetrical federalism. Comments by three anonymous referees as well as by the participants of the conference on "Heterogeneity and Democracy" at the Wissenschaftszentrum Berlin (June 25-26, 2009) are also gratefully acknowledged. Needless to say, all remaining errors are my own.

\section{Declaration of Conflicting Interests}

The author declared no potential conflicts of interests with respect to the authorship and/or publication of this article.

\section{Funding}

The author received no financial support for the research and/or authorship of this article.

\section{Notes}

1. National minorities form a subcategory of the wider genus of ethnic minorities. Following Birnir (2009), "an ethnic group is defined by members of the group who consider themselves ethnically distinct from other groups in society" and "this identification centers on a characteristic that is difficult to suppress, such as language, location, or race" (p. 24).

2. The use of the terms federation and federal political system in this article is in line with the definitions provided by Watts (1999b, pp. 6-7).

3. To my knowledge, Congleton, Kyriacou, and Bacaria (2003) provide the only exception regarding the choice of asymmetrical institutions. They model constitutional negotiation over regional competencies between a center and federal units. Two conditions are found to be sufficient for a de jure asymmetrical outcome: substantial differences in demands for local services and differences regarding the political risk regions associate with transferring competencies to the central level. Yet their model assumes the security costs for the center to be uniform across all regions (p. 172) and thereby fails to account for the fact that almost all existing de jure asymmetrical federations are multinational states where peripheral national minority regions pose a much greater risk to the center than RBUs inhabited by the majority population. 
A notable exception concerning the asymmetrical federal game itself is Solnick's (1998) analysis of central and regional strategies in early Russia. Trying to answer the question of whether Russia would survive after the dissolution of the Soviet Union, the author delivers a range of insights about asymmetrical federations more generally that is referred to in more detail in Section 3 of this article.

4. The following considerations draw inspiration from Young's (1994) model of a secession game in the case of Quebec. In his modeling, however, asymmetry does not play a role.

5. The material dimension already provides reasonable grounds to assume conflict over who controls T. Conflict potential is exacerbated by the nationalist dimension that plays the decisive role in the context of multinational states (Hechter, 2000, p. 71).

6. For a proof of how variation of payoffs can produce cooperation in a prisoner's dilemma, see Tsebelis (1990, pp. 68-72). De Figueiredo and Weingast (2005) argue more generally that the center can increase benefits for marginal regions with low exit costs and thereby ensure the survival of a federation (p. 128).

7. The full title of Tarlton's contribution that appeared in Journal of Politics in 1965 was "Symmetry and Asymmetry as Elements of Federalism: A Theoretical Speculation."

8. The Spanish constitution had originally introduced a fast track to autonomy for the nationality-based units of the Basque Country, Catalonia, and Galicia and for Andalusia by referendum (Constitución Española, 2003, Art. 151).

9. According to an institutions-as-equilibrium account, the possibility of selfenforcing federalism involves constantly restraining two dynamics from turning into their extreme - the tendency of the center to overawe its units leading to a centralization of the system and the tendency of the units to undermine federalism by free riding, which leads to its peripheralization (De Figueiredo, McFaul, \& Weingast, 2007, p. 163).

10. In light of this, it could be questioned why rational minority elites would agree to an asymmetrical deal in the first place. However, I argue only that de jure asymmetry carries strong incentives for its own abolishment that have to be taken into account, not that these incentives do of necessity lead to a modification of asymmetrical rules that, after all, have the status of constitutional law.

11. Explaining the empirical processes with the game theoretical logic developed in Sections 1 and 2 constitutes the analytic part of the Russian narrative in the sense of the approach made famous by Bates, Greif, Levi, Rosenthal, and Weingast (1998).

12. Romanization of Cyrillic words follows the U.S. Library of Congress system for Russian-English transliteration with the exception of the word Soviet and the name Yeltsin, which are spelled as is common in English.

13. For the full spectrum of separatist activism in Russia's ethnic regions between 1990 and 1994 (including assertions of the right to natural resources or of the 
right to have a regional currency and unilateral rising of administrative status), see Treisman (1997, pp. 226-228).

14. The final draft for the new constitution was accepted through a plebiscite in December 1993 by $58.4 \%$ of all citizens but rejected by the majority of the population in the group of republics (Heinemann-Grüder, 2000, pp. 174-175).

15. The bilateral treaties can be retrieved from http://constitution.garant.ru/DOC_7100 .htm (retrieved March 23, 2009).

16. The first federal military intervention in 1996 was followed by a period of de facto sovereignty in the interwar period between 1997 and 1999. In 1999, the Putin government initiated the second war to force the secessionist republic back into the legal and territorial framework of the Russian Federation by all military means. As the center never really opted for a cooperative strategy, it remains subject to counterfactual reasoning if a political asymmetrical solution at an early stage could have prevented the conflict. Several authors argue that it could (Alexseev, 1999; Heinemann-Grüder, 2000, p. 286; Hughes, 2002, p. 62).

17. Bilateral and ad hoc center regional relations are also prominently mentioned in discussions of Spanish federalization (e.g., Moreno, 2004, p. 3). With its asymmetries, Spain should therefore be an obvious case for further application of the model.

\section{References}

Agranoff, R. (Ed.). (1999a). Accommodating diversity: Asymmetry in federal states. Baden-Baden, Germany: Nomos.

Agranoff, R. (1999b). Intergovernmental relations and the management of asymmetry in federal Spain. In R. Agranoff (Ed.), Accommodating diversity: Asymmetry in federal states (pp. 94-117). Baden-Baden, Germany: Nomos.

Alexseev, M. A. (1999). Center-periphery conflict in post-Soviet Russia: A federation imperiled. New York: St. Martin's.

Bates, R. H., Greif, A., Levi, M., Rosenthal, J. L., \& Weingast, B. R. (1998). Analytic narratives. Princeton, NJ: Princeton University Press.

Bednar, J. (2009). The robust federation: Principles of design. Cambridge, UK: Cambridge University Press.

Birnir, J. K. (2009). Ethnicity and electoral politics. Cambridge, UK: Cambridge University Press.

Burgess, M. (2008). Das Paradox der Diversität: Asymmetrischer Föderalismus aus vergleichender Perspektive [The paradox of diversity: Asymmetrical federalism in comparative perspective]. In Europäisches Zentrum für Föderalismus-Forschung (Ed.), Jahrbuch des Föderalismus 2008 (pp. 103-116). Baden-Baden, Germany: Nomos.

Burgess, M., \& Gress, F. (1999). Symmetry and asymmetry revisited. In R. Agranoff (Ed.), Accommodating diversity: Asymmetry in federal states (pp. 43-56). BadenBaden, Germany: Nomos. 
Chapman, T., \& Roeder, P. G. (2007). Partition as a solution to wars of nationalism: The importance of institutions. American Political Science Review, 101, 677-691.

Congleton, R. D., Kyriacou, A., \& Bacaria, J. (2003). A theory of menu federalism: Decentralization by political agreement. Constitutional Political Economy, 14, 167-190.

Constitución Española [Spanish constitution] (3rd ed.). (2003). Biblioteca de Legislación. Madrid: Civitas Ediciones.

De Figueiredo, R. J. P., McFaul, M., \& Weingast, B. R. (2007). Constructing selfenforcing federalism in the early United States and modern Russia. Publius, 37(2), 160-189.

De Figueiredo, R. J. P., \& Weingast, B. R. (2005). Self-enforcing federalism. Journal of Law, Economics, and Organization, 21(1), 103-135.

Dogovor Rossiiskoi Federatsii i Respubliki Tatarstan [Treaty of the Russian Federation and the Republic of Tatarstan]. (1994, February 15). Retrieved April 7, 2009 , from http://constitution.garant.ru/DOC_1448120.htm

Federativnii Dogovor [Federal Treaty]. (1992, March 31). Retrieved April 7, 2009, from http://constitution.garant.ru/DOC_70280.htm

Filippov, M., Ordeshook, P. C., \& Shvetsova. O. (2004). Designing federalism: $A$ theory of self-sustainable federal institutions. Cambridge, UK: Cambridge University Press.

George, A. L., \& Bennett, A. (2005). Case studies and theory development in the social sciences. Cambridge, MA: MIT Press.

Gorenburg, D. (2003). Minority ethnic mobilisation in the Russian Federation. Cambridge, UK: Cambridge University Press.

Greif, A., \& Laitin, D. D. (2004). A theory of endogenous institutional change. American Political Science Review, 98, 633-652.

Hechter, M. (2000). Containing nationalism. Oxford, UK: Oxford University Press.

Heinemann-Grüder, A. (2000). Der heterogene Staat. Föderalismus und regionale Vielfalt in Rußland [The heterogeneous state. Federalism and regional diversity in Russia]. Berlin: Arno Spitz.

Herrera, Y. M. (2005). Imagined economies. The sources of Russian regionalism. Cambridge, UK: Cambridge University Press.

Hug, S. (2005). Federal stability in unequal societies. Constitutional Political Economy, $16,113-124$.

Hughes, J. (1996). Moscow's bilateral treaties add to confusion. Transition, 2(19), 39-43. Hughes, J. (2002). Managing secession potential in the Russian Federation. In J. Hughes \& G. Sasse (Eds.), Ethnicity and territory in the former Soviet Union: Regions in conflict (pp. 36-68). London: Frank Cass.

Kahn, J. (2002). Federalism, democratization, and the rule of law in Russia. Oxford, UK: Oxford University Press. 
Keating, M. (1999). Asymmetrical government: Multinational states in an integrating Europe. Publius: The Journal of Federalism, 29(1), 71-86.

Keating, M. (2001). So many nations, so few states: Territory and nationalism in the global era. In A. G. Gagnon \& J. Tully (Eds.), Multinational democracies (pp. 39-64). Cambridge, UK: Cambridge University Press.

Konstitutsiya Rossiiskoi Federatsii [Constitution of the Russian Federation]. (2006). Moscow: NORMA.

Kymlicka, W. (1998). Is federalism a viable alternative to secession? In P. Lehning (Ed.), Theories of secession (pp. 111-150). London: Routledge.

McGarry, J. (2002). Federal political systems and national minorities. In A. L. Griffiths (Ed.), Handbook of federal countries 2002 (pp. 416-447). Montreal: McGill-Queen's University Press.

McGarry, J. (2005). Asymmetrical federalism and the plurinational state. In F. Geerkens (Ed.), Third International Conference on Federalism. Federalism: Turning diversity into harmony. Sharing best practices. Speeches, contributions and conclusions (pp. 302-324). Tielt, Belgium: Lannoo.

Medvedev, N.P. (2003). Rol' deklaratsii o gosudarstvennom suverenitete RSFSR i federativnogo dogovora $\mathrm{v}$ protsesse transformatsii territorial' no-politicheskogo ustroistva sovremennoi Rossii [The role of the RSFSR's sovereignty declaration and the Federal Treaty in the process of transforming the territorial-political design of contemporary Russia]. In R. G. Abdulatipov (Ed.), Voprosy natsional'nykh i federativnykh otnoshenii (pp. 20-27). Moscow: RAGS.

Moreno, L. (2004). Federalization in multinational Spain (Unidad de Politicas Comparadas (CSIC) Working Paper 07-04). Retrieved July 2, 2009, from http://www .ipp.csic.es/doctrab2/dt-0704.pdf

Münkler, H. (2003). Die neuen Kriege [The new wars]. Reinbek, Germany: Rowohlt Verlag GmbH.

Obydenkova, A. (2005). Institutional tools of conflict management-asymmetrical federalism in ethnic-territorial conflicts: Quantitative analysis of Russian regions. Peace, Conflict and Development, 7, 251-280.

Palermo, F., Hrbek, R., Zwilling, C., \& Alber, E. (2007). Auf dem Weg zu asymmetrischem Föderalismus? [On the way toward asymmetrical federalism?]. BadenBaden, Germany: Nomos.

Rao, M. G., \& Singh, N. (2004). Asymmetric federalism in India (University of California, Santa Cruz International Economics Working Paper 04-08). Retrieved April 7, 2009, from http://ssrn.com/abstract=537782

Requejo, F. (2001). Federalism and national groups. International Social Science Journal, 53(167), 41-49.

Solnick, S. (1998). Will Russia survive? Center and periphery in the Russian Federation. In B. R. Rubin \& J. Snyder (Eds.), Post-Soviet political order: Conflict and state building (pp. 58-80). London: Routledge. 
Stepan, A. (2000). Russian federalism in comparative perspective. Post-Soviet Affairs, 16(2), 133-176.

Stepan, A. (2001). Arguing comparative politics. Oxford, UK: Oxford University Press. Stepanov, V. (2000). Ethnic tensions and separatism in Russia. Journal of Ethnic and Migration Studies, 26(2), 305-332.

Swenden, W. (2002). Asymmetric federalism and coalition-making in Belgium. Publius, 32(3), 67-87.

Tarlton, C. D. (1965). Symmetry and asymmetry as elements of federalism: A theoretical speculation. Journal of Politics, 27(4), 861-874.

Tishkov, V. (1997). Ethnicity, nationalism and conflict in and after the Soviet Union: The mind aflame. Thousand Oaks, CA: SAGE.

Treisman, D. S. (1997). Russia's "ethnic revival": The separatist activism of regional leaders in a postcommunist order. World Politics, 49, 212-249.

Treisman, D. (2007). The architecture of government: Rethinking political decentralization. Cambridge, UK: Cambridge University Press.

Tsebelis, G. (1990). Nested games: Rational choice in comparative politics. Berkeley: University of California Press.

Umnova, I. A. (1996). Sovremennaya rossiiskaya model' rasdeleniya vlasti mezhdu federaciei i ee sub'ektami [The Russian contemporary model of the separation of power between the federation and its subjects]. Moscow: INION RAN.

Umnova, I. A. (1998). Konstitutsionnye osnovy sovremennogo rossiiskogo federalizma [The constitutional foundations of Russian contemporary federalism]. Moscow: DELO.

Von Beyme, K. (2005). Asymmetric federalism between globalization and regionalization. Journal of European Public Policy, 12(3), 432-447.

Watts, R. L. (1999a). The Canadian experience with asymmetrical federalism. In R. Agranoff (Ed.), Accommodating diversity: Asymmetry in federal states (pp. 118-136). Baden-Baden, Germany: Nomos.

Watts, R. L. (1999b). Comparing federal systems (2nd ed.). Montreal: McGillQueen's University Press.

Watts, R. L. (1999c). The theoretical and practical implications of asymmetrical federalism. In R. Agranoff (Ed.), Accommodating diversity: Asymmetry in federal states (pp. 24-42). Baden-Baden, Germany: Nomos.

Young, R. A. (1994). The political economy of secession: The case of Quebec. Constitutional Political Economy, 5, 221-245.

\section{Bio}

Christina Isabel Zuber is a research assistant to the chair in comparative politics at the University of Cologne in Cologne, Germany. 